\title{
CONSIDERAÇÕES GERAIS EM TÔRNO DA REGIÃO LAGUNAR DE CANANEIA-IGUAPE
}

W. Besnard

A faixa litorânea do Estado de São Paulo, pode ser dividida em duas porções nitidamente distintas - a costa norte e a sul.

A primeira, começa na fronteira com o E. do Rio de Janeiro e vai até Santos. Caracteriza-se por declives montanhosos, formados pela Serra do Mar e seus contrafortes, moldura natural do planalto interior, elevados a uma altura de 600 a 800 metros acima do nível do mar. Sua constituição é, geralmente, rochosa, entrecortada de vales mais ou menos profundos, que descem da Serra, cujo cenário é, de quando em vez, quebrado pela presença de pequenas praias. Em vários locais, entre São Sebastão e Ubatuba, por exemplo, abrem-se amplos e profundos vales. Quando o massiço orográfico se desvia do mar, deparam-se praias extensas, emoldurando terrás baixas, em cujas proximidades encontram/se fundos de lôdo. No resto observam-se penhascos dispersos em meio a um terreno formado por resíduos ou detritos continentais, por entre o qual fluem rios e ribeirões. A própria configuração da região não permite que êsses contingentes de água doce sejam volumosos. Sobrevoando-se o terreno, fica-se desde logo surpreendido com a fato de que os cursos d'água, a partir do espigão da Serra, correm não em direção ao mar como seria natural, mas em sentido oposto. Lugares há em que, à distância superior a vinte quilômetros, a rêde hidrográfica ruma para o interior, une-se ao sistema fluvial do Paraná, para, então, no extremo sul do Brasil, ingressar no Oceano. Em síntese, conforme muito bem assinalou RAJA GABAGLIA (1922, p. 62), o litoral norte paulista caracteriza-se por possuir "ausência de baixadas e a presença de falhas".

A costa sul é, ao contrário, constituida, sobretudo, por uma série de praias extensas que guarnecem territórios relativamente baixos, interrompidos, aqui e acolá, por elevações de secundária importância. Depois de Santos, a Serra do Mar divorcia-se progressivamente da linha da costa, nela surgindo sòmente mais além, ao sul do E. de São Paulo. Êsse desvio origina, em primeiro lugar, o aparecimento de uma região cortada de depressões, por vêzes acentuadas, entre montes um tanto elevados, para depois apresentar configurações totalmente achatadas e baixas. Ao sul do Estado, uma grande depressão aberta entre os contrafortes da Serra do Mar dá origem à bacia fluvial do Ribeira de Iguape, para onde se escoam as águas de uma extensão de cêrca de 10 a 12 mil quilômetros quadrados. Essas águas, salvo alguns pequenos cursos que se atiram na laguna ou no mar, são captadas pelo grande rio que desemboca nas circunvizinhanças da cidade de Iguape, ao norte do sistema lagunar Iguape- 
Cananéia. Só depois disso é que a maior parte da sua massa líquida ruma para o Oceano, nêle penetrando por meio de duas barras situadas muito próximas: a da Ribeira e a de Icaparra.

O simples nome de "laguna de Cananéia" atribuido a essa bacia, não dá uma idéia nítida da sua configuração, muito complexa, sobretudo devido ao formato alongado e estreito que caracteriza a porção situada mais ao sul. Por isso, preferimos empregar o têrmo "região lagunar". Possui ela mais de 100 quilômetros de extensão, distando, os pontos mais afastados do mar, cêrca de $20 \mathrm{~km}$.

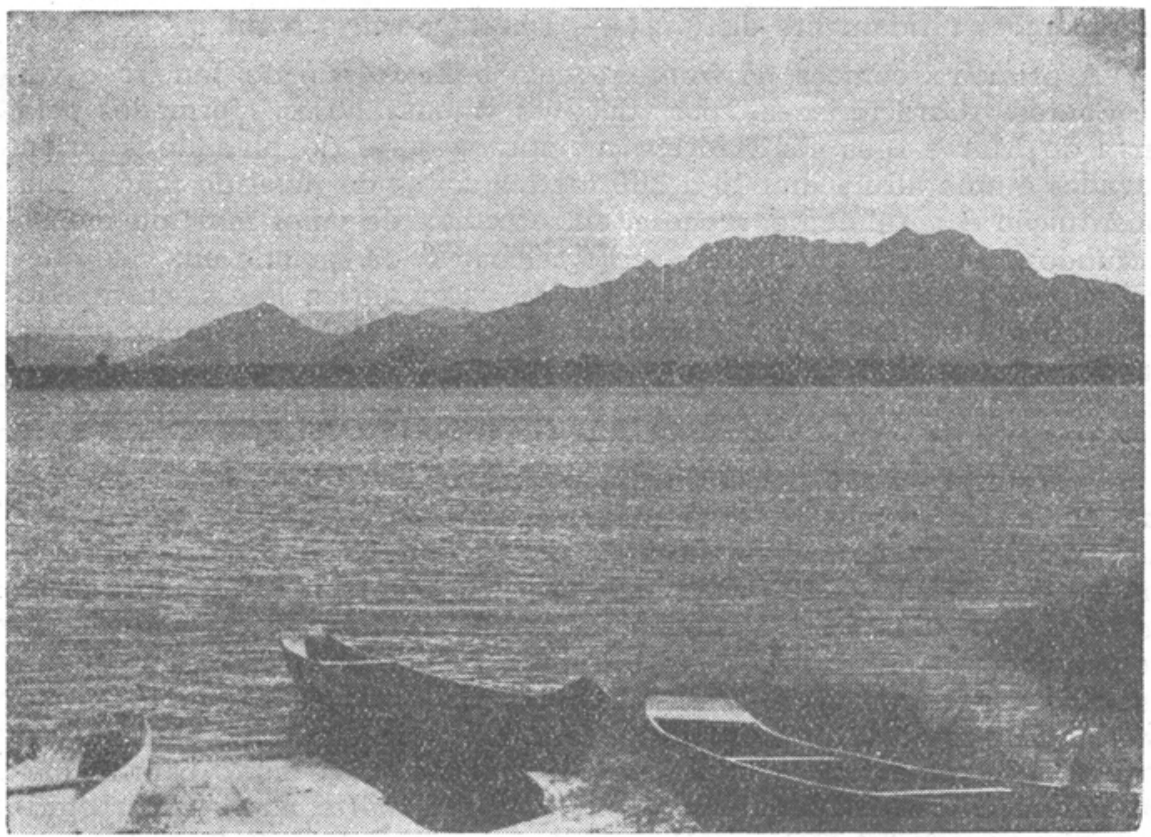

FIG. 1 - Mar de Cananéia, visto da I. Comprida, bem em frente de Cananéia. Em segundo plano, a Serra de Itapitanguí, situada a $40 \mathrm{~K} \mathrm{~m}$ em línha réta.

Em suas linhas mestras, o conjunto é representado pelo corpo principal da laguna, que exibe a conformação de um rio de largura média, não excedente de $1 \mathrm{~km}$., com o comprimento de, aproximadamente, 75 $\mathrm{km}$. Segue paralelamente à orla oceânica, dela ficando separado por uma faixa arenosa e estreita, representada pela Ilha Comprida. E a "praia barreiro" ou "restinga", conforme a concepção de BRANNER (1915, p. 83), que assim se pronuncia - "Ilha ou península delgada, semelhante em forma a um pontal, formado por sedimentos ao longo e parallelo ás linhas da costa". Em ambas as extremidades dessa laguna, acham-se situadas as duas principais barras de penetração. A do norte, franqueada a pequenas embarcações, nos momentos de fluxo, é perigosa por causa dos bancos de areia movediça que se encontram à sua entrada. 
A do sul, ao contrário, pôsto requeira certas precauções, é accessível mesmo a barcos de calado médio, nela encontrando-se profundidades de cêrca de 9 metros, em maré baixa. O canal, em sí, apresenta fundos que vão de 12 a 18 metros.

A porção norte da laguna tem um único leito cuja largura não é superior a $1 \mathrm{~km}$. Descendo-se em direção oposta, nos dois têrços do seu comprimento, reparte-se ela em dois braços - o Mar de Cananéia e o Mar de Cubatão, êste situado entre o continente e a ilha de Cananéia na qual, em sua face SW, encontra-se a cidade do mesmo nome. A parte sul dessa ilha tem a largura de, aproximadamente, $8 \mathrm{~km}$.. No ponto cardial oposto ao norte dessa ilha, diante do canal, encontra-se a zona mais ampla do sistema lagunar - a baía de Trepandé, onde desembocam os dois braços pré-citados. A região principal é separada do mar pela Ilha Comprida, que mede $73 \mathrm{kms}$. de extensão e tem uma largura que varia de 2 a $4 \mathrm{~km}$.. E assinalado, em ambas as extremidades, por dois massiços montanhosos, contornados por dois outros braços representados pelo Ribeira e pelo Ararapíra, que se lançam ao mar através de estreitos de importância secundária - a Barra do Ribeira, ao norte de Iguape e a de Ararapíra, que ladeiam os dois massiços já referidos.

Êste esquema, de aparência muito simples é, entretanto, sensìvelmente complicado, sobretudo ao sul, em virtude da existência de uma série de baías, divertículos é "marigols" salgados. Entre êstes há numerosos que são em parte navegáveis, oferecendo o aspécto de verdadeiros rios.

Tôda a regiäo é essencialmente arenosa, tendo raros afloramentos de terras argilosas, avermelhadas, existindo em certos lugares elevações rochosas de pequenas dimensões.

\section{ENSÁIO HIPOTÉTICO SÔBRE A GENESE DA REGIÃO}

Para que se possa formular e expôr qualquer hipótese a respeito da região lagunar de Cananéia é necessário, primeiramente, que se tome em consideração o território que se encontra mais ao sul. Um exame atento dos terrenos e das águas existentes entre Iguape e Paranaguá sugere ter sido a seguinte a configuração primitiva dessa parte do litoral. O recúo da Serra do mar para o interior, começando ao sul de Santos, acentua-se um pouco antes de Iguape. Mais ao S., nas proximidades do paralelo de Paranaguá, depois de mudança brusca, segue o rumo do litoral. Aí é que, em épocas passadas, parece ter existido um golfo profundo e amplo, semeado de ilhas montanhosas, das quais algumas de superfície muito grande, formando pequenos mas verdadeiros massiços montanhosos, com altitude superior a 600 metros. Entre essas ilhas existia uma, provàvelmente a maior, que se achava mais distante, na direção do mar largo. Seus vestígios estão representados pela atual ilha do Cardoso. A oeste, entre ela e o continente, verdadeira cadeia de ilhas e ilhotas formam uma espécie de barragem que divide o golfo em duas grandes baías. Em virtude do assoreamento provocado pelo material vindo do continente e que decorre do desgaste das mesmas ilhas, os canais e estreitos se fo- 


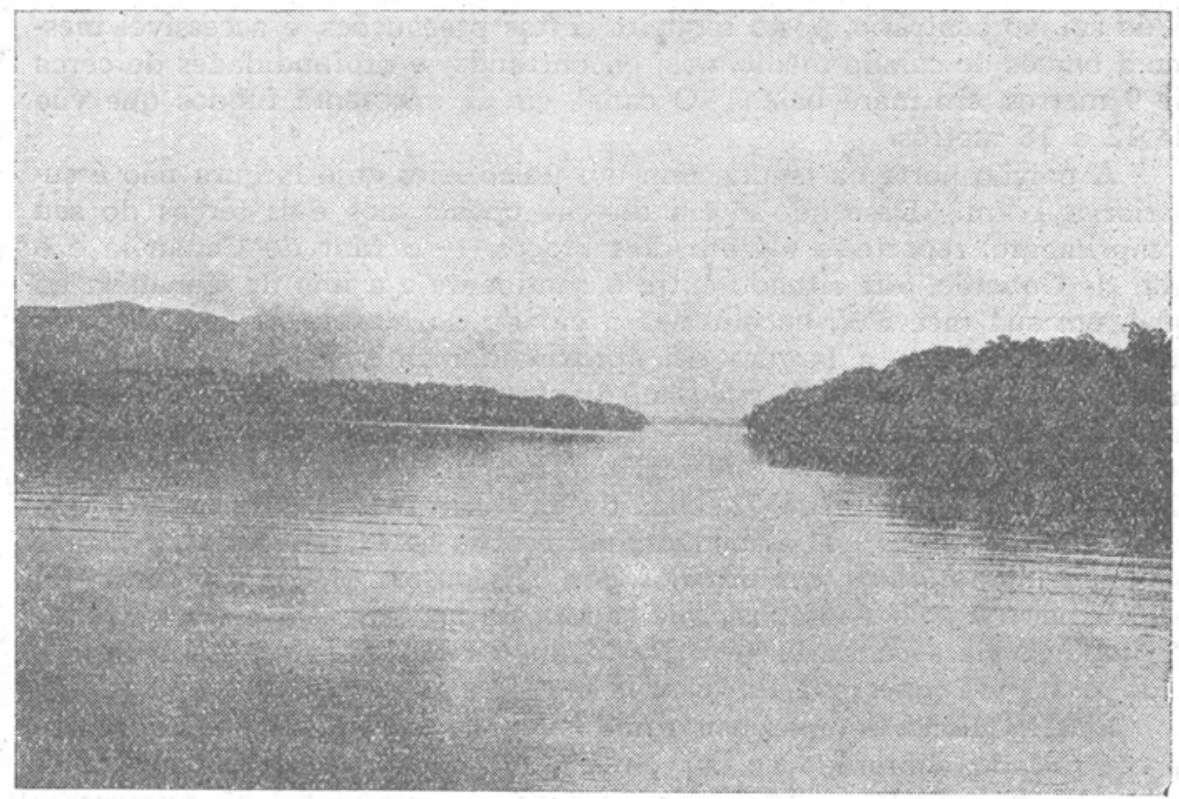

FIG. 2 - Baía de Trepande. Aspecto característico das zonas de mangue.

ram entupindo progressivamente e tôda a zona transformou-se em terras baixas e paludosas, tal como a vemos nos dias de hoje, semeada de colinas e pequenas lombadas. Pérsiste um único estreito, devido provàvelmente à sua situação que permite a penetração dos golpes do mar e das correntes de maré. Esse estreito é o mesmo que separava a antiga ilha do Cardoso do resto. Emitindo essa opinião, só nos referimos à porção N. do antigo golfo que, no decurso de sua evolução, se transformou na região lagunar de Cananéia.

$$
\text { * * }
$$

Por essa época, a grande ilha (I. do Cardoso) devia possuir área e forma muito diversas da atual, extensão verdadeiramente enorme, sendo relativamente baixa do lado do mar grosso. Esta parte da ilha, fazia saliência pronunciada na direção do oceano, englobando e até ultrapassando os limites das ilhas de Bom Abrigo, Cambriú e, talvez mesmo, Castilho. Tão grande massa, colocada como anteparo aos ventos e tempestades dominantes dos rumos S. e SE. aumentava a ação erosiva do mar, provocando desgaste da saliência do cabo e mantendo aberto o estreito (atual Ararapira). Entrementes, na baía N., dava-se a invasão pelos cursos d'água enquanto que no fundo da baía as aluviões foram aos poucos se acumulando e sendo retidas pelos manguesais. Tal hipótese é sustentada não só pela predominância dos ventos de S. e SE., como também pela ocorrência habitual de tempestades, do mesmo quadrante. 


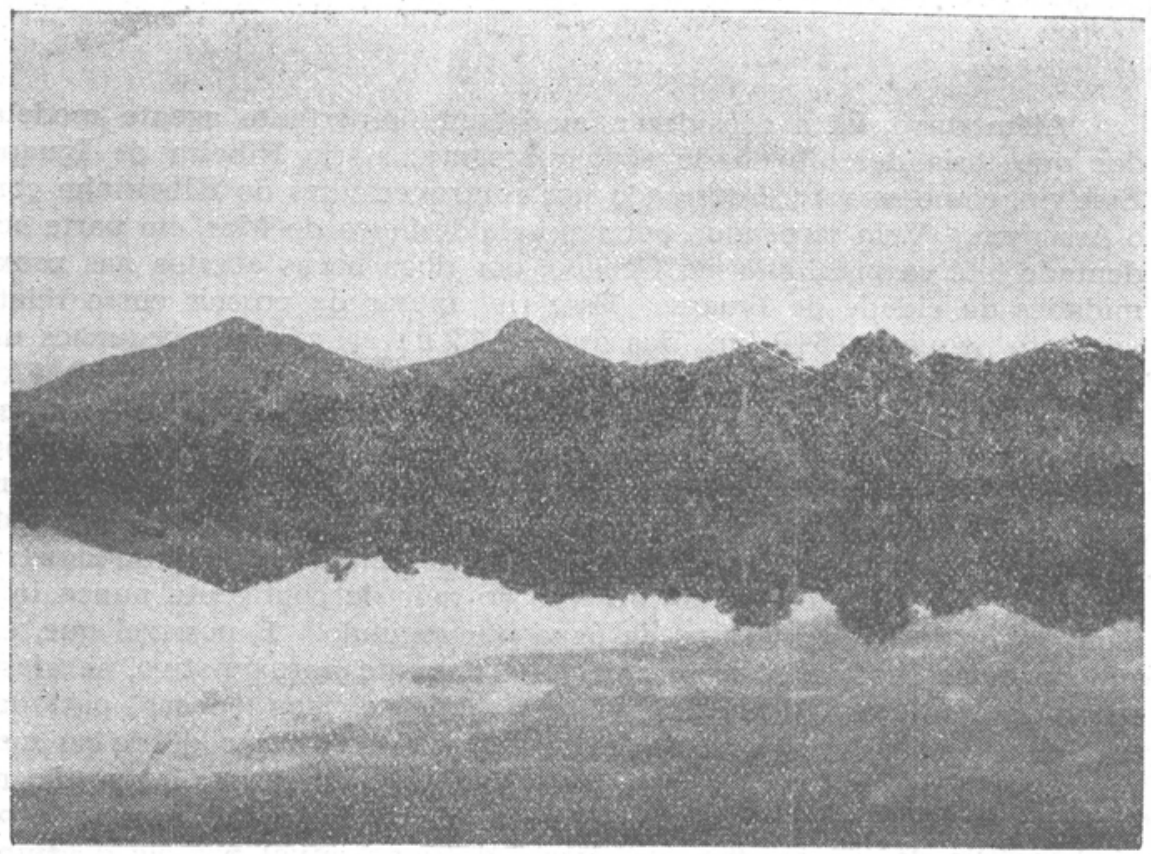

FIG. 3 - Canal de Ararapira, margem continental. As colinas em segundo plano, sẽo os supostos vestígios de antigas ilhas.

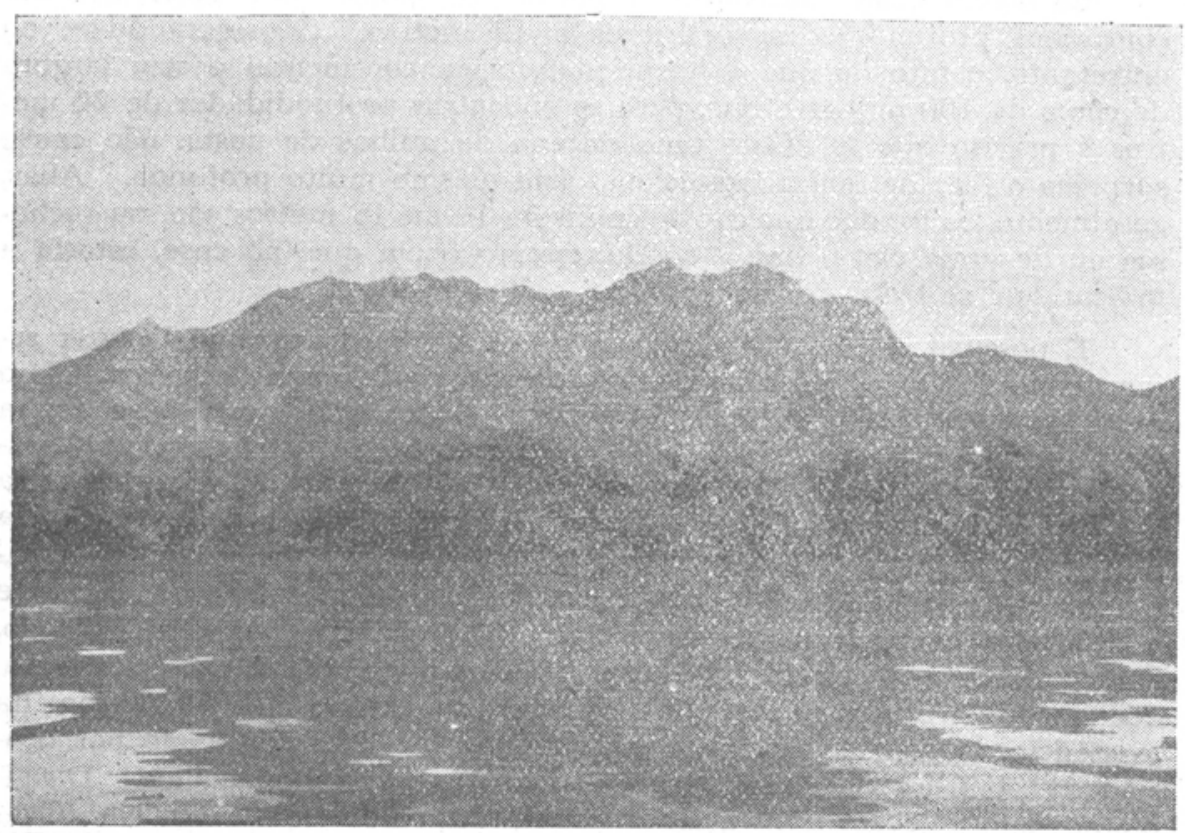

FIG. 4 - O maciço da I. do Cardoso. No centro, o Pico do Cardoso $(622 \mathrm{~m})$. Em primeiro plano, o Canal de Ararapira. 
Além disso, há a considerar, ainda, um importante agente modelador que teria desempenhado ação marcante: o rio Ribeira de Iguape. Esse rio, como se sabe, é formado por contravertentes do Ribeirinha com o Assunguí. Vem serpeando por um vale da Serra do Mar, em parte acidentado, até se precipitar no Oceano, por duas bocas abertas nas proximidades da cidade de Iguape. Êsse rio, apesar de possuir curso relativamente pequeno $(510 \mathrm{~km}$., dos quais, 143 navegáveis por pequenos navios, até Xiririca, e mais $78 \mathrm{~km}$. até Ribeira, por meio de canôas) é de grande potência, visto como atúa preponderantemente no trabalho de escoamento e drenagem de uma região extensa e rica em precipitações atmosféricas. Assim, em Juquiá, possui êle a largura média de $175 \mathrm{~m}$. com profundidade média de $5 \mathrm{~m}$. A velocidade da corrente, conquanto variável de acôrdo com a época do ano, é de cêrca de 3 a 5 quilômetros horários. Isso ocasiona o lançamento ao mar de contigente nunca inferior, em média, a $10.000 \mathrm{~m}^{3}$ de água por segundo. E possível que, em um ou outro sentido, o nosso cálculo, conquanto aproximativo, se afaste sensivelmente da realidade. Incontestàvelmente, em épocas passadas, êsse débito deve ter sido muito maior, atingindo talvez o dôbro ou mesmo o triplo do aqui previsto. Oportunamente, volveremos à questão relativa à provável atuação dêsse rio na formação da laguna, durante o período médio da sua criação, bem como do papel atual por êle desempenhado.

As lagunas são relativamente pouco profundas. Até agora, não encontramos profundidades superiores a 19 metros. Considerando-se, no entretanto, o fato de que a nossa plataforma continental possui largura de cêrca de 100 milhas e que, para se encontrar profundidades de 20 metros é preciso que se afaste uma dezena de milhas da costa, não causa surprêsa o fato de que a laguna não seja mesmo muito profunda. Aliás, geralmente, os fundos que ultrapassam de 10 ou 15 metros são, ou rochosos ou de areia clara, fina e sólida, circunstância que, no caso, estaria a indicar que se trata de um provável golfo inicial.

E possível que as últimas fases de formação do sistema lagunar sejam, contudo, do ponto de vista geológico, relativamente recentes. Isso pode ser corroborado pelo seguinte fato: - No setor norte, logo acima da península e da ilha de S. Sebastião, encontra-se a enseada de Caraguatatuba. Essa região é desprovida de lagunas, devido, certamente, a diferenças que caracterizam as duas zonas consideradas, bem como pela influência da enorme massa orográfica formada pela conjunção da grande ilha acima citada, com o contraforte da Serra o que impede totalmente a ação dos ventos do quadrante SW. O processo é, pois, modificado, apenas em seus detalhes, pôsto que o efeito não sofra alteração alguma, acarretando a obstrução da baía. Em fins de 1948, fomos informados da existência de ossadas em vasto bananal, achado êsse verificado por ocasião da abertura de canais de drenagem no terreno alagadiço. Dirigímo-nos para o local e constatámos que se tratava de ossos de baleia. Conseguimos tirar uma das vértebras, achando-se o resto da carcaça dispersn pelo solo. Por outro lado, fragmentos do arcabouço dêsses cetáceos já 


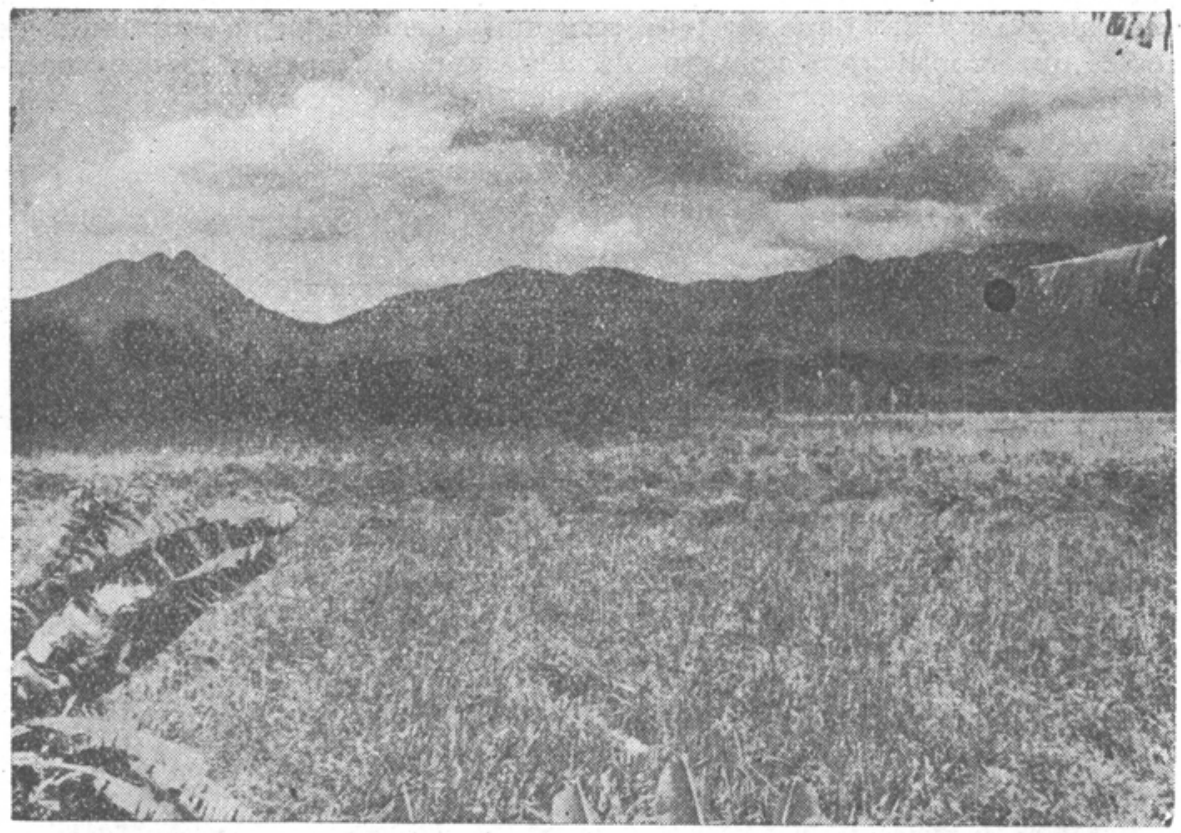

FIG. 5 - Planície formada por terrenos le aluvião, característica de terras baixas, ocupando o lugar do antigo golfo.

haviam sido encontrados inúmeras vêzes e, em uma delas, retirara-se um esqueleto quasi completo. Aí, a natureza do terreno é idêntica à das partes baixas da região de Cananéia, isto é, muito arenosa mas recoberta por uma camada de terra vegetal um tanto mais espessa. Explica-se essa maior riqueza em humus pelo fato de não ser a região formada por acentuado recuo da Serra do Mar, tal como acontece na região sul, mas por espécie de chanfradura aberta na cadeia de montanhas que, em tempos idos, deve ter abrigado uma baía. Segue-se daí que não sòmente as partes baixas coletavam todos os produtos consequentes do trabalho de erosão, mas, também, todos os detritos orgânicos provenientes dos declives escarpados e cobertos de vegetação, para lá encaminhados pelas enxurradas. O local em que se deu o encontro da ossada, achava-se situado em linha reta, a cêrca de $41 / 2 \mathrm{~km}$. do mar. Foi encontrada, aproximadamente, a $1^{\mathrm{m}} 20$ da superfície do solo. E forçoso considerar que o lençol de águas subterrâneas encontra-se quasi à flor do solo, geralmente a 40 ou $60 \mathrm{~cm}$., razão pela qual, aliás, o terreno precisou ser drenado para o desenvolvimento do bananal, abrindo-se nele uma rede de canais de escoamento. O lençol subterrâneo é composto de águas de infiltração provenientes das colinas das circunvizinhanças e da própria planície, de resto recobertas por vegetação bastante densa. São águas ácidas, cujo $\mathrm{pH}$, fora da época chuvosa, se aproxima de 5,5. A circulação dessas águas 
no subsolo arenoso deve ser feita com muita facilidade; no entretanto, os ossos que mantiveram contácto com elas sofreram apenas ataque superficial.

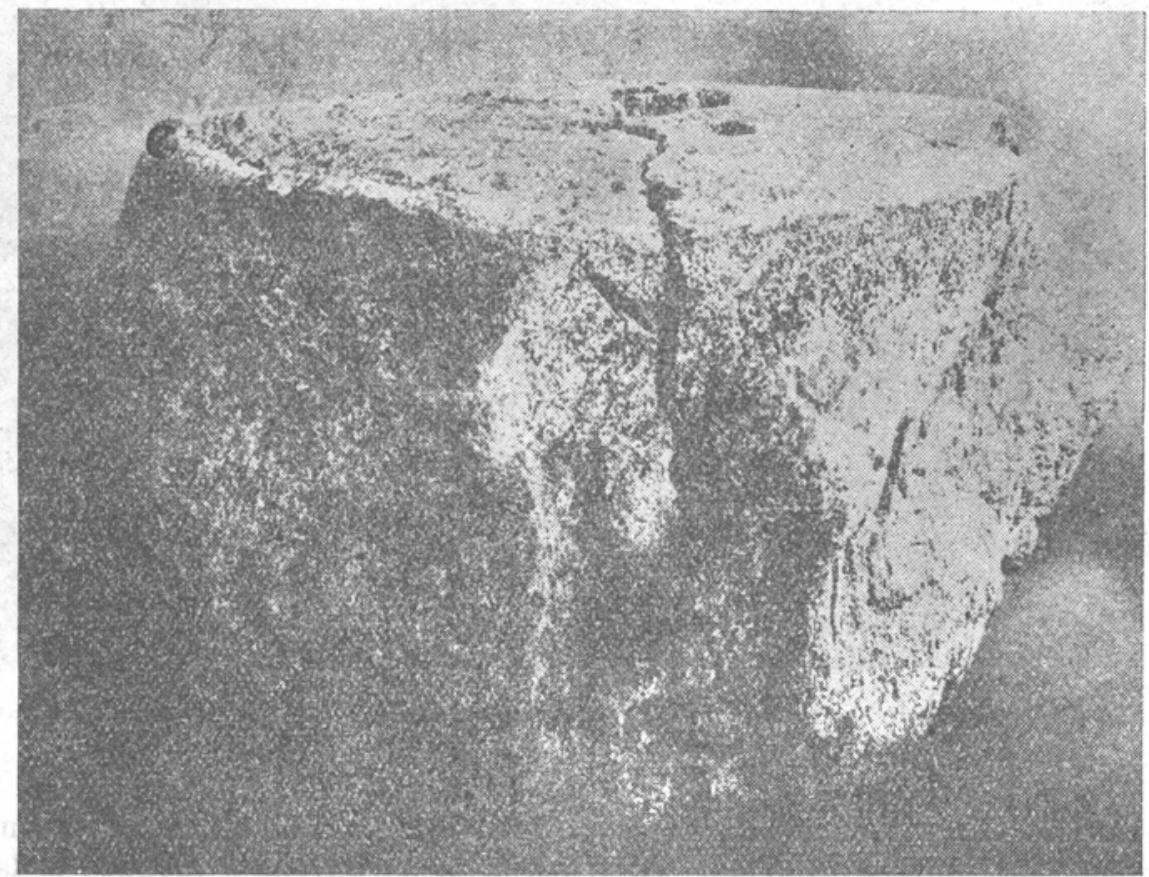

FIG. 6 - Vértebra de Baleia estraída de um bananal situado no fundo do golfo de Caraguatatuba.

O revestimento total da vértebra achava-se dissolvido, mas a porção esponjosa do corpo, em si, ainda persistia. Por outro lado, não havia qualquer traço de petrificação. Êsses fatos parecem indicar que em época relativamente recente, a praia encontrava-se ainda a cêrca de $41 / 2$ $\mathrm{km}$., terra a dentro.

As ilhas Comprida e de Cananéia, sofreram, talvez, sublevamentos tectônicos locais, que não teriam ultrapassado de 2 a $3 \mathrm{~m}$. Aliás, KRONE, (1914, p.30) diz: "Em alguns logares, por exemplo, no Mar Pequeno e no Canal de Iguape, repetem-se piçarra e areia uma segunda vez e parece por isso que na época quaternaria houve diversas oscilações locaes na altura do terreno".

No que respeita à antiguidade dessas ilhas, sobretudo quanto a parte sul na Ilha Comprida, ela se deduz do fato de que sôbre o substrato arenoso, que presentemente ultrapassa o nível médio do mar de alguns centímetros, acha-se depositada uma camada de areia da mesma origem, mas fortemente impregnada de matérias ferruginosas. Essa camada, que dá 
a impressão de grês em formação, tem cêrca de $1^{\mathrm{m}} 50$ de espessura. As matérias ferruginosas e, provàvelmente, em parte, as de origem orgânica, formaram um todo com a areia, emprestando a esta um colorido pardo escuro. Muito embora a consistência do material contido nessa camada seja evidentemente frágil, ocorre, com frequência, o desprendimento de blocos inteiros de mais ou menos $1 \mathrm{~m}^{3}$.

No local é conhecido o fato da entrada da barra rumar para o norte, erodindo, anualmente, pelo menos, 1 metro de terras pertencentes à Ilha Comprida, enquanto que o outro lado, devido à deposição de areia, progride na mesma direção. Várias casas de pescadores, situadas na Ponta da Trincheira (face sul da ilha) ou desapareceram tragadas pelos desmoronamentos ou foram, em tempo, transferidas para lugares seguros situados mais ao norte.

Para ilustrar o desenvolvimento hipotético dos fenômenos consecutivos da gênese dessa região, encontraremos, mais adiante, quatro esquemas por meio dos quais, partindo do estado primitivo, atingiremos o atual, passando por estádios intermediários de transformação. Para não tornar a questão sobremodo complexa, faremos apenas representar aqui a parte sul da laguna onde, na nossa opinião, se desenvolveram os fenômenos determinantes do processus. Quanto à parte norte, teria também sofrido as consequências dêle decorrentes. Aqui, porém, nem tudo se teria passado com grande simplicidade, dada a presença no local de um rio de proporções consideráveis. Muito provàvelmente, forçado pelas circunstâncias, êsse rio, em época bastante remota, teria mudado de curso, excavando novo álveo situado mais ao norte, na atual Ribeira e descarregando as suas águas no Oceano por intermédio da Barra do Ribeira. Assim sendo, o rio teria interrompindo as suas relações diretas com o sistema lagunar.

Cumpre esclarecer o porque do seu atual transvasamento na laguna, o que merece ser considerado com algum detalhe. A antiga cidade de Iguape achava-se situada ao pé de pequeno monte, mesmo à beira da laguna. $\mathrm{O}$ rio passava a alguns quilómetros da cidade. Vindo no rumo desta, o curso fluvial derivava sùbitamente para o N., penetrando em desfiladeiro rasgado entre dois acidentes orográficos. Essa ocorrência desagradável, complicava sèriamente o problema dos transportes por via fluvial, que estabelecia a ligação entre o porto marítimo e o hinterland, já na época bastante desenvolvido. Como o tráfico fluvial era feito por meio de canôas, decidiram as autoridades de Iguape abrir um canal, ou melhor uma passagem, que permitisse a navegação direta de pequenas embarcações. KRUG (1939, p. 23), diz: "Este canal foi feito lá pelo ano de 1830 . Com o tempo, o canal de $4,40 \mathrm{~m}$. foi-se alargando tanto que dá, atualmente, passagem às águas do Ribeira e a foz dêste rio ficou completamente obstruida pela vegetação que aí cresceu".

Terminada a construção da passagem, as águas por ela se precipitaram, aceitando de pronto o novo leito, aliás perfeitamente navegável. Estava, portanto, satisfeío o desejo da população local, cuja máxima aspiração consistia, no dizer de ALMEIDA (1945, p. 30), em "fazer desaparecer o trabalho de transbordo das mercadorias das carroças para as 


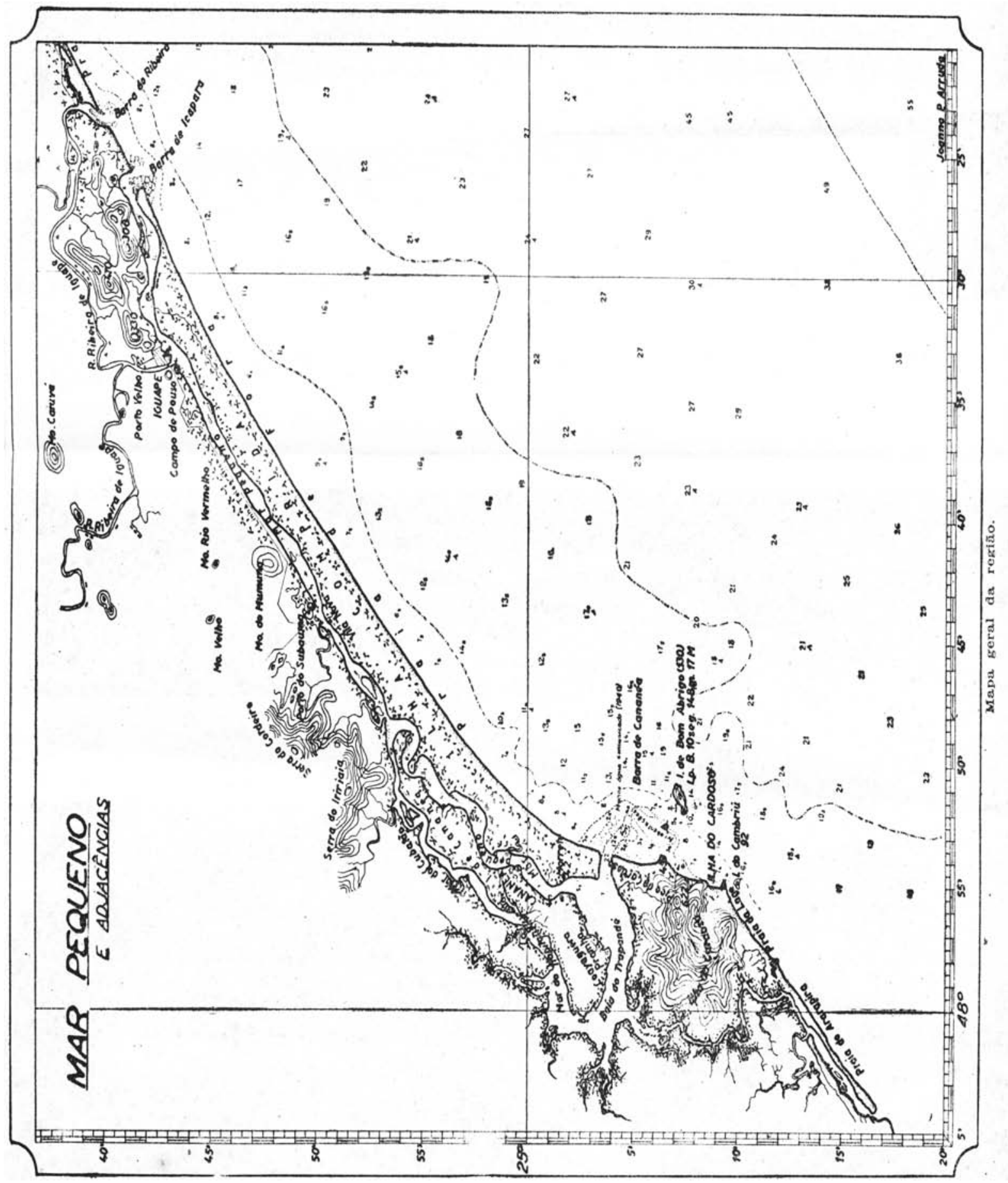


embarcações e vice-versa". Refere-se o autor ao transporte que, de Iguape, era feito pela estrada que ia ter ao Porto Velho.

Segundo, porém, o testemunho de SCHMIDT (1914, p. 8), "em 1889 , mais ou menos, a Diretoria do $5^{\circ}$ Distrito marítimo foi incumbida de proceder ao fechamento do já então célebre vallo; procedendo á sondagem e mais trabalhos preliminares, procuraram executal-a, com a construção de um revestimento de pedras que, do porto velho, corrigindo a margem esquerda do vallo, chegava até o logar escolhido para proceder á barragem; ésta foi feita imergindo colchões de pedras e com trabalhos auxiliares nas bahias ou saccos que tinha a margem esquerda do vallo, etc.". Diz mais além o mesmo autor que "apezar de estar a barragem quasi concluida, faltando apenas um metro para alcançar o nivel d'água nas marés baixas, por ordem superior foi suspenso o serviço e tudo abandonado".

Talvez mais tarde, ao estudarmos melhor a questão na parte norte da região lagunar, tenhamos de volver novamente ao assunto.

Por ora, esquematizemos o que acaba de ser exposto. Preliminarmente, o rio desembocava na extremidade da margem que lhe serve atualmente de estuário. Tal como acontece em todos os cursos potâmicos considerados como "trabalhadores", a declividade do Ribeira de Iguape teria sido naturalmente mais pronunciada do que a atual (aplainamento de partes absorvidas). Da mesma maneira, sua correnteza deve ter sido muito maior. Por outro lado, o desbaste no revestimento vegetal ainda não havia sido iniciado, sendo também muito maior o seu volume de água. Segue-se que a quantidade de detritos em suspensão, provenientes do trabalho erosivo, deveria ter sido considerável. Ora, como é natural, êsses produtos eram depositados no estuário, onde a força da correnteza perdia grande parte do seu dinamismo. Obstruido o estuário, a parte baixa do rio ficaria sujeito à tendência de elevar o seu nível.

Do outro lado do pequeno massiço montanhoso de Iguape, situavase uma região baixa, bem mais restrita, cujas águas eram drenadas pelo sistema de pequeno rio: o Una da Aldeia. Uma parte das águas dêsse curso fluvial vinha do vale que separa o morrete de Iguape do que the fica fronteiro. Encontramo-nos, aqui, diante de fenômeno que afeta as leis determinan'es da erosão. Segundo elas, as fontes dos cursos d'agua têm a tendência de se deslocar; ou melhor, de recuar. Enquanto isso, o estuário, aos poucos, teria elevado o seu nível em consequência do assoreamento e da formação de zonas aluvionais. O grande rio viria lutar com a formação montanhosa, na sua parte mais baixa, isto é, justamente em face do vale que o separava da zona em que se situa a bacia do rio Una da Aldeia. Do outro lado, o tributário do pequeno rio Una prosseguia no trabalho contínuo de desgaste, aplainando dessa maneira o vale e, ao refluir, destruiria, por seu turno, a linha de separação das águas. Teria sido dessa maneira que os contingentes do rio Ribeira de Iguape, embaraçados pelo acúmulo de areia e outros sedimentos existentes no seu estuário e cujo escoamento era ainda agravado pelo avanço paulatino da Ilha Comprida, mudaram o seu curso, indo lançar as suas águas na bacia do Una da Aldeia. O aspécto geral e atual do novo setor, isto é, do ponto de captação situado na Barra do Ribeira, parece sustentar tal tese, pois 
apesar das facilidades decorrentes da erosão, não se apresenta bastante largo para ter servido, durante muito tempo, de talvegue a um rio como o aqui tratado.

Tendo-se desviado da zona da Ribeira, continuando a carrear enormes quantidades de areia e tendo, ainda, como sobrecarga, o resultante da excavação do novo leito, o rio teria assoreado o novo estuário, voltanto pouco a pouco ao nível habitual.

Isso explicaria o fato de, no momento da abertura do canal, o rio ter voltado a seguir o seu curso primitivo.

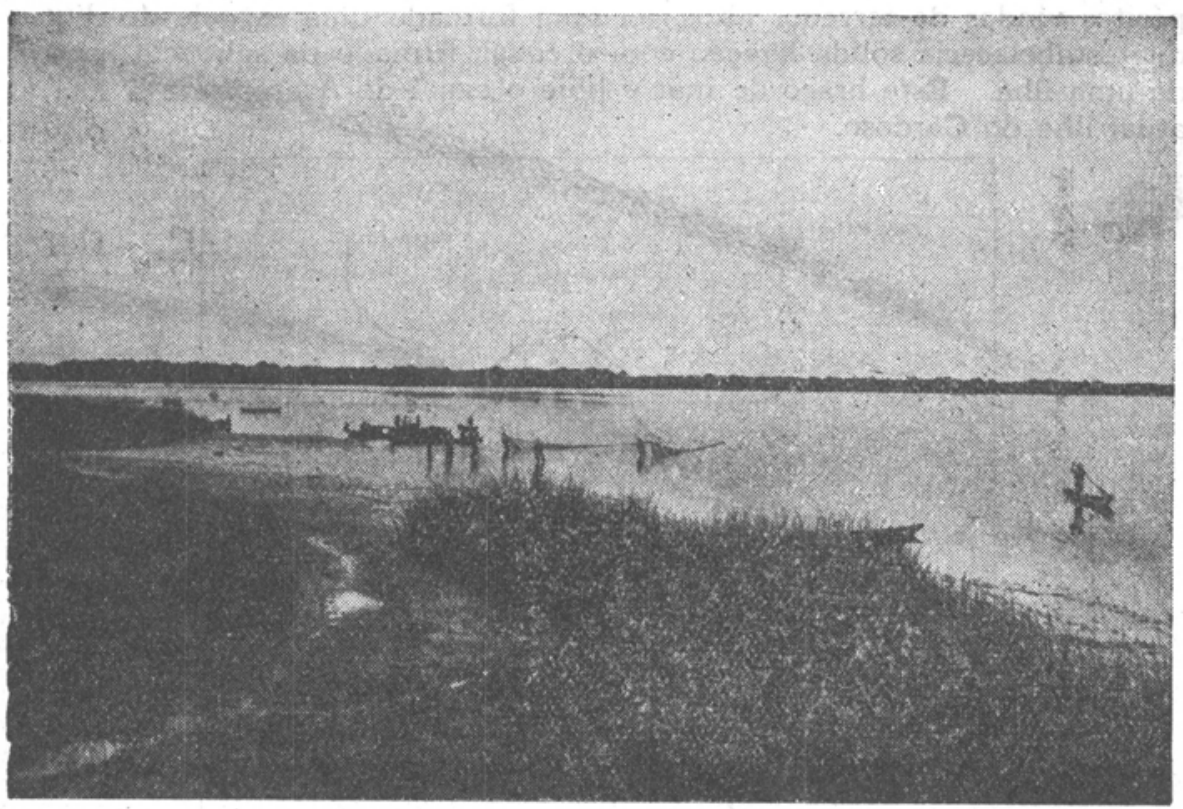

FIG 7 - Assoreamento do Mar Pequeno, diante da embocadura do Ribeira de Iguape.

* $\quad *$

Examinando os esquemas que se seguem, cumpre alertar o leitor para que não venha a tomá-los ao pé da letra, pois, não só devido à falta de tempo, mas, sobretudo, à carência de meios materiais, não nos foi possível fixar, com precisão, os limites reais da pressuposta baía. Ela seria, provàvelmente, muito maior e de feição mais complexa do que ora imaginamos, na sua parte SW. Como já dissemos, é também admissível que, primitivamente, tenha ela abrangido no seu todo as terras baixas das circunvizinhanças, formando, talvez, com a baía de Paranaguá, um só golfo semeado de grandes e montanhosas ilhas. Nesse caso, no fundo dêste imenso golfo, a ação retentora dos manguesais deve ter sido 
inicialmente muito ativa, desde que, por se achar ao abrigo da influência direta dos ventos e tempestades dos quadrantes S. e SE., deveria ter assumido a mesma configuração aluvional que se nota no fundo da Enseada de Caraguatatuba e do qual já fizemos referência mais atrás.

Portanto, o primeiro e o mais importante dos fenômenos, parece ter sido a separação entre a baía ainda existente de Paranaguá e a aqui conjecturada. E razoável imaginar que, em tempos remotos, devido à presença de uma série de ilhas representadas, em nossos dias, por pequenas formações montanhosas, constituindo uma zona favorável ao assoreamento, quer provocado pelo impulso das tempestades de SE., quer pelos depósitos vindos de terrenos altos, ter-se-ía formado uma espécie de dique que estabeleceria sólida ligação com o canal, firmado na saliência brusca de uma ilha. Êste braço de mar é hoje o canal de Ararapira e a ilha a atual ilha do Cardoso.

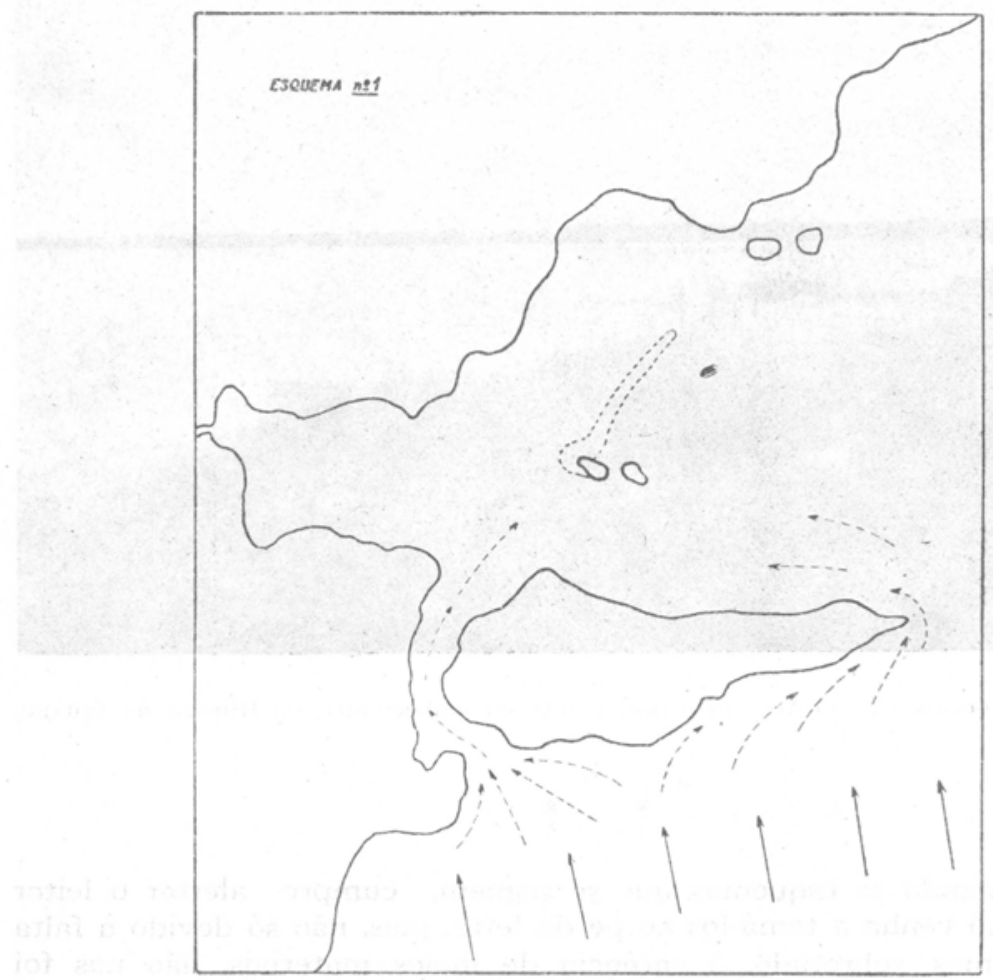

FIG. 8 - Esquema I.

Esquema 1 - Nele representamos um fenômeno local em que, depois da subdivisão do golfo (talvez mesmo antes disso), vamos encontrar a seguinte situação: uma bəía que se aprofunda pelo terreno (cêrca de $25 \mathrm{~km}$. de extensão) protegida, ao sul, por terras baixas, consolidadas devido à interferência de diversos acidenthes geográficos pequenos, mas 
montanhosos. No extremo sul, encontra-se uma ilha (a E.) representando considerável massiço montanhoso (tendo, agora, em média 600 metros de altura). Atrás dela, na parte que fica entre o massiço e o continente, abre-se um estreito. Ao norte, alonga-se uma baía (em sentido horizontal) profunda na face SW. que se abre a SE. Ao norte, não longe da grande ilha encontram-se duas pequenas ilhas de constituição rochosa, cujos vestígios atuais se fazem representar pelo morro de S. João, situado na Ilha de Cananéia, e pelo Morrete fronteriço que se ergue à margem da Ilha Comprida. E quasi certo que, na direção $\mathrm{NE}$. de $\mathrm{S}$. João, tenha existido um baixío de cascalho extenso, cujos vestígios ainda podem ser observados pela sua ocorrência em diversas partes da ilha, mesmo no leito de alguns "marigots". São locais onde, em relação ao nível médio atual, os prováveis baixíos deveriam ter de 0 a $5 \mathrm{~m}$., de profundidade. O resto da baía possui fundos que atingem, em média, de 15 a 20 metros. Mais ao norte, nas proximidades da porção saliente da costa, encontram-se duas outras ilhas rochosas, dotadas apenas de poucos meiros de altitude. Os sinais da existência dessas ilhas são muito evidentes e podem ser observados entre o continente e a extremidade norte da ilha de Cananéia e a cêrca de dois quilômetros ENE dêsse ponto, no local denominado Pedrinhas.

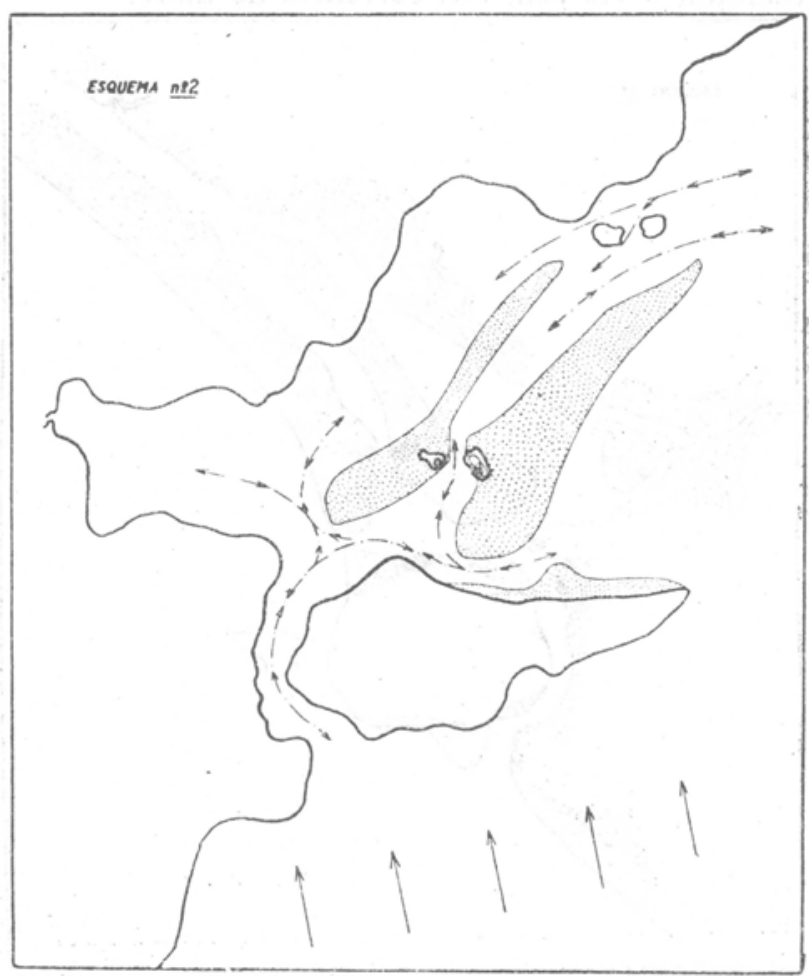

FIG. 9 - Esquema II. 
No esquema I, a direção dos ventos predominantes está figurada por uma série de flexas não pontuadas, enquanto que as pontilhadas indicam o movimento das águas impelidas por êsses mesmos ventos.

Esquema II - Representa êle os primórdios evolutivos da baía. $\mathrm{O}$ início do trabalho de erosão acha-se aí assinalado. A grande ilha começou a ser atacada na sua parte baixa e mais exposta. Os produtos decorrentes da erosão são conduzidos pelos movimentos das águas impulsionadas pelos ventos e, em seguida, depositados na zona protegida pela carcaça geológica da ilha. Neste ponto, porém, entra em jôgo um novo fator - as correntes de maré, menos violentas, mas de regime permanente. Sua fôrça e velocidade, aliás, são acrescidas por obstáculos representados pelos bancos de areia que aumentam à medida que prossegue o trabalho de erosão da ilha. Essas correntes impedem a deposição do material erodido diante da passagem situada ao norte do estreito. $\mathbf{O}$ vai-vem das marés conserva tôdas as passagens permanentemente abertas. Mais ao norte, uma cadeia formada por alguns contrafortes montanhosos, precedida por duas ilhas rochosas, desvia e reparte as correntes de maré, o que mantém a separação dos dois bancos de areia que representam embrióes das ilhas Comprida e de Cananéia. As flexas pontilhadas, representam o vai-vem das correntes de maré.

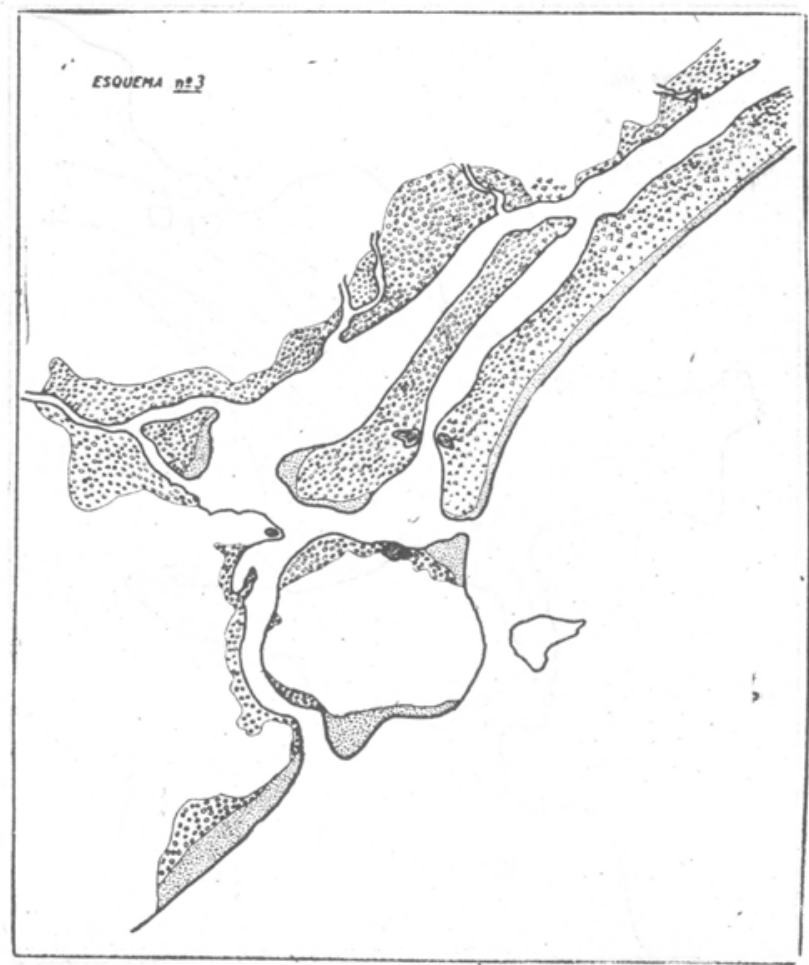

FIG. 10 - Esquema III 
Esquema III - Refere-se ao processo de consolidação de resíduos pelos manguesais e da invasão de lama, areia e detritos orgânicos diversos vindos do interior, trazidos pelos cursos dágua e enxurradas. Aliás, os dois últimos fatores, de medíocre importância no decurso das estações desprovidas de chuvas, adquirem considerável potência mecânica no período das águas, no qual o líquido proveniente de milhares de quilômetros quadrados escoa-se para a laguna.

A lenta mas enorme potência retentora dos manguesais, secundada pela presença do anteparo da Ilha Comprida, protegida contra a violência do mar, entra, então, em ação. Nas partes mais elevadas, surgem as primeiras florestas e, orlando a praia exterior, aparecem gramíneas e a vegetação característica de pequenos bosques. Da grande ilha, cuja ponta avançava mar a dentro, restam apenas a parte alta e montanhosa reduzida quasi às proporções da atual Ilha do Cardoso e os ventígios de um massiço separado, dominador da porção saliente da ilha, atualmente representada pelo Bom Abrigo. $O$ estreito, situado entre a ilha montanhosa e o continente, em consequência do início do assoreamento, começa a exibir formações aluvionais dos lados dos mangues, sobretudo do lado do continente, ponto aliás já muito invadido pela mangrovia.

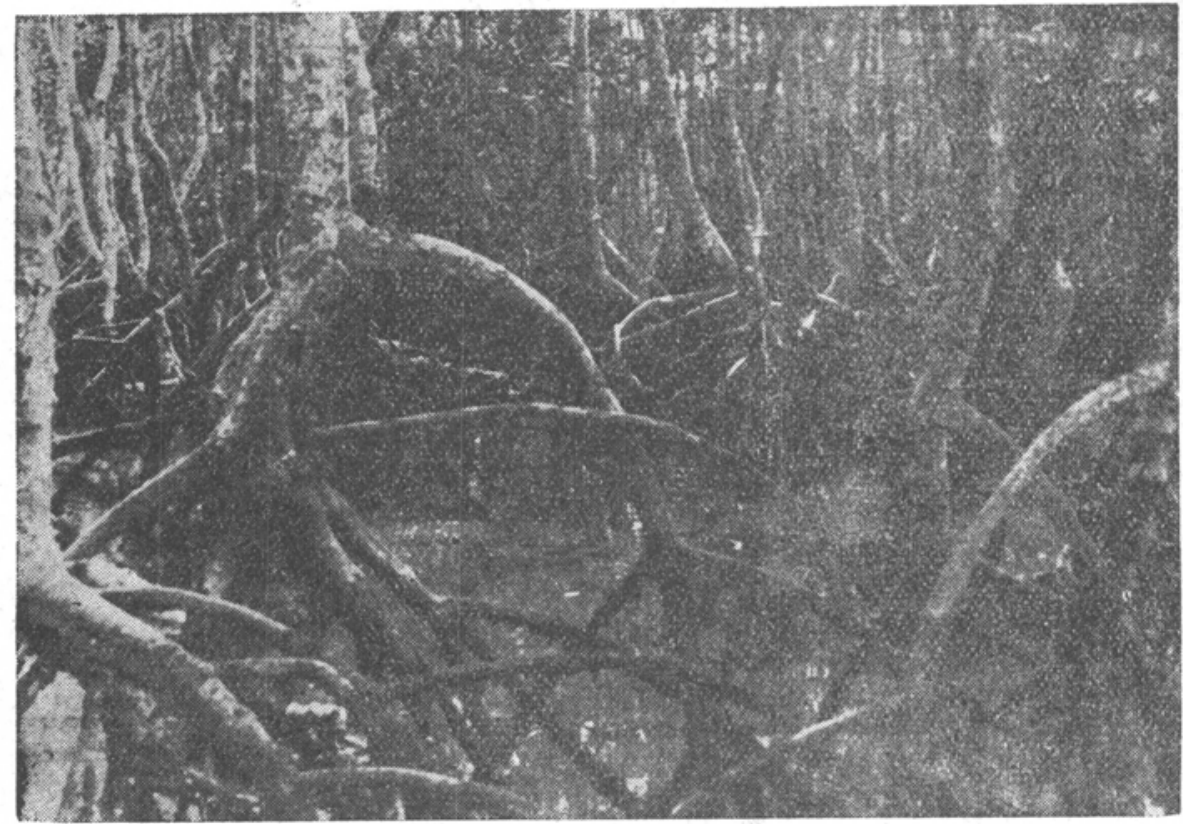

FlG. 11 - Fixação por mangues. Margem continental do Mar do Cubatão.

Esquema IV - Estado atual. O trabalho de obstrução prossegue, conquanto para nós, aparentemente, tenha êle terminado. As grandes extensões de mangue, tendo finalizado o seu trabalho de consolidação e 
fixação, concentram-se nas partes baixas ainda sujeitas ao balanceamento das marés, em particular ao longo dos numerosos "marigots" que abrem sulcos em ilhas e nas partes profundas de terras pouco elevadas. Os dois estreitos que contornavam a ilha de Cananéia subsistem, o mesmo acontecendo com o antigo canal, conquanto êste esteja protegido da ação das tempestades por meio de comprida faixa de areia consolidada pela vegetação aí crescida. A ilha, cuja saliência se vê no esquema I, sofreu aplainamento na sua parte mais exposta ao dinamismo dos agentes de erosão, ficando o restante na linha de costa. A fôrça das vagas atuou sôbre as duas minúsculas ilhotas restantes, deparando-se, mais além, com a mole resistente de imensa praia arenosa, sôbre a qual se quebrava óbliquamente. Afigura-se-nos que a ação externa, conquanto não de todo terminada, está, hoje em dia, consideràvelmente reduzida.

No interior, atrás do anteparo natural da Ilha Comprida, estabelece-se embate quotidiano, cada vez mais árduo, de um lado, entre os depósitos aluvionais consequentes do acúmulo de detritos continentais e a invasão do mangue e, de outro, entre as correntes de maré e as enxurradas de água doce. Os dois últimos fatores esforçam-se por manter a passagem livre, mas, na sua violência, carreteiam numerosos bancos de areia fina e vasa. Desde que o assoreamento se apoie sôbre uma margem, o mangue disso se aproveita e ganha terreno.

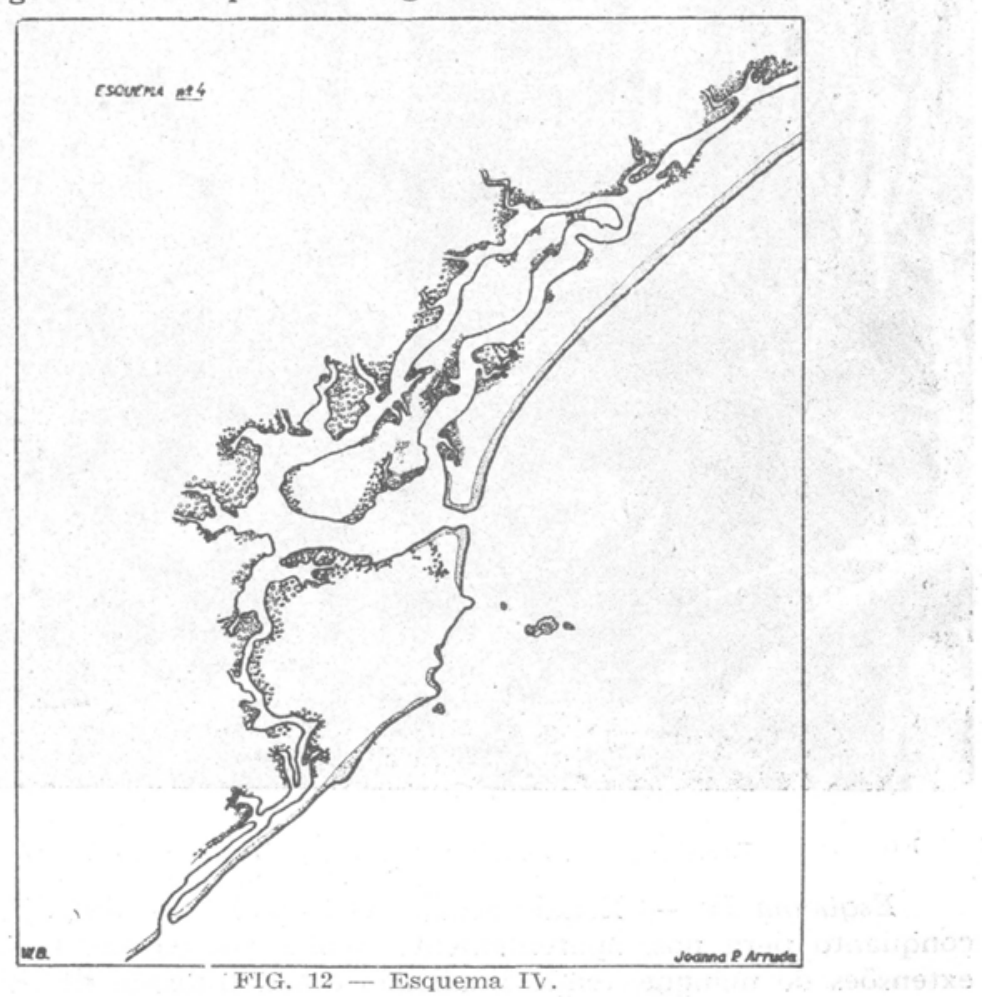


A atividade do Ribeira de Iguape, após o seu presumível retôrno para a laguna, deve ter modificado consideràvelmente' o processus evolulutivo da região. Antes da abertura do novo leito, tôda a parte norte da laguna, isto é, os 20 ou $30 \mathrm{kms}$ situados antes da Barra de Icapara, achavam-se sòmente submetidos à influência do balanceamento das marés, bem como a de alguns cursos de água, lentos e sem importância. Era a manutenção do "statu quo". A abertura do canal do Pôrto Velho até o Pôrto de Iguape e a chegada das águas do rio modificaram completamente a situação. A ação do rio foi dupla e antagônica. Primeiramente o assoreamento e, em seguide, o auxílio prestado às correntes de maré visando a manutenção dos canais.

O assoreamento como também a obstrução devido aos transportes do rio parecem ter sido muito importantes e ameaçam ocasionar, dentro de prazo muito curto, enormes modificações em tôrno da evolução da região. De fato, o pôrto de Iguape, que recebia com muita frequência a visita de navios de não pequena tonelagem, encontra-se presentemente isolado por bancos de areia que reduzem as vias de penetração a um máximo de 3 metros, por ocasião da baixamar. Na Barra de Icaparra existe, em nossos dias, uma passagem muito estreitā, só praticável por embarcações de pequeno calado, isso mesmo em períodos de grandes marés. RAJA GABAGLIA (1.c., p. 65) diz: "A Barra de Icaparra que dá entrada ao Mar Pequeno, está hoje abandonada, apesar de sôbre o banco da entrada e na maré baixa, a sonda ter acusado $3,5 \mathrm{~m}$.,".

Há poucos anos, grandes vapores do Loide Brasileiro chegavam a Iguape, depois de penetrar pela Barra de Cananéia, subindo pelo Mar Pequeno. De há alguns anos para cá, isso se tornou impossível. Encontramo-nos, assim, diante de um fenômeno de rápida e bilateral obstrução, isto é, processando-se em duas direções: rumo à Barra de Icaparra e no sentido do corpo principal da laguna - em direção à Cananéia. Cabe, aqui, uma pergunta: "Quais serão as consequências decorrentes da situação atual?" São três, no mínimo, as possibilidades que podem apresentar: Primeira, o estreito de Icapara, em virtude do assoreamento a que se acha submetido, ou por efeito de uma tempestade de maiores proporções que venha de E. ou de NE., acabará por ficar intransponível. Essa é uma hipótese plausível, pôsto que o rio oporá insignificante resistência ao bloqueio, pela facilidade que terá em derivar as suas águas para o sul (Mar Pequeno). Segunda, em ponto de acentuado estrangulamento ou de formação de bancos de areia do Mar Pequeno, ao sul de Iguape, em virtude do transporte de areia e lôdo feito pelo rio, o assoreamento dividirá a laguna, solução essa pouco provável em consequência do movimento das marés. Terceira, o assoreamento que já forma uma barreira de bancos em tôrno da desembocadura e que, diante da cidade, já se encontram fixados por vegetação (fenômeno ocorrente, no decurso dos últimos 15 anos) desviará novamente e em rítmo progressivo, as águas do rio para o seu braço secundário e para a Barra do Ribeira de Iguape. 
Afigura-se-nos que a primeira hipótese é näo sòmente verossímil mas até muito provável. Nêsse caso, será lógico que a desembocadura se desloque para o sul, reduzindo por deposição aluvional a largura do canal mais importante e aproximando-se progressivamente de Pedrinhas, ponto de divisão dos Mares Pequeno, de Cananéia e do Cubatão. Examinando-se a carta hidrográfica da região (N. 1702, Brasil - Costa Sul, Mar Pequeno, 30-IX-42), pode-se facilmente ter uma idéia do futuro leito. 